\title{
Pentraxin-3 mediates prosurvival actions of interferon tau in bovine luteinized granulosa cells
}

\author{
Raghavendra Basavaraja, Senasige Thilina Madusanka¹, Ketan Shrestha, Emilia Przygrodzka², \\ Monika Marzena Kaczmarek $\mathbb{B}^{2}$ and Rina Meidan(1) \\ ${ }^{1}$ Department of Animal Sciences, The Robert H. Smith Faculty of Agriculture, Food and Environment, The Hebrew \\ University of Jerusalem, Rehovot, Israel and ${ }^{2}$ Department of Hormonal Action and Mechanisms, Institute of Animal \\ Reproduction and Food Research, Polish Academy of Science, Olsztyn, Poland
}

Correspondence should be addressed to R Meidan;Email: rina.meidan@mail.huji.ac.il

\begin{abstract}
Pentraxin 3 (PTX3), a multimeric glycoprotein, is implicated in various biological functions. PTX3 was shown to be elevated in the corpus luteum (CL) of early pregnant ewes; however, its role in sheep or other ruminants' CL during this reproductive stage or how it is regulated remain unknown. Here we explored the role of PTX3 and its relationship with interferon-tau (IFNT; the pregnancy recognition signaling molecule during early pregnancy in domestic ruminants) in bovine luteinized granulosa cells (LGCs). IFNT robustly elevated PTX3 expression in bovine LGCs, and significantly stimulated its expression in luteal endothelial cells, along with CL slices; yet, LGCs were the most responsive and sensitive among these luteal models. ALK2/ALK3/ALK6 kinase inhibitor, dorsomorphin, dose-dependently inhibited basal and IFNT-elevated PTX3 expression in LGCs. In contrast, ALK4/5/7 inhibitor, SB431542, did not alter basal and TGFB1-induced PTX3. We found that recombinant human PTX3 itself moderately but significantly increases LGC numbers. Because PTX3 is highly expressed in bovine LGCs, we next examined the impact of lowering endogenous PTX3 levels with siRNA. PTX3 silencing decreased the viable cell numbers and reversed IFNT actions on cell viability, percentage of proliferating cells, and on two key survival/death genes: BIRC5 encoding surviving protein, and FASL - a death-inducing signal. Interestingly, thrombospondin-1, a known luteal proapoptotic factor, was inversely related to PTX3 in LGCs. Together, these findings suggest a novel role for PTX3 during early pregnancy, as mediator of IFNT prosurvival actions supporting CL maintenance during this reproductive stage.

Reproduction (2020) $160603-612$
\end{abstract}

\section{Introduction}

The establishment and maintenance of pregnancy in mammals require the continuous function of the corpus luteum $(\mathrm{CL})$ and its ability to secrete progesterone (Norwitz et al. 2001, Lonergan \& Forde 2015, DeMayo \& Lydon 2020). However, the mechanism that sustains $\mathrm{CL}$ function is species specific. In primates, a chorionic gonadotrophin (hCG in humans) is secreted by the trophoblast; it provides direct luteotrophic support to the $\mathrm{CL}$ (Devoto et al. 2009). In domestic ruminants the factor responsible for maternal recognition of pregnancy (MRP) is interferon tau (IFNT), which is secreted from the mononuclear trophoblastic cells of the elongating embryo (Roberts et al. 1999, Bazer \& Thatcher 2017). IFNT abrogates the uterine luteolytic pulses of prostaglandin F2 alpha (PGF2a), thus preventing CL regression (Spencer et al. 1996, Mann et al. 1999). However, in addition, the extra-uterine, endocrine effects of IFNT were reported (Oliveira et al. 2008, Yang et al. 2010, Romero et al. 2013, Basavaraja et al. 2019). Endocrine delivery of IFNT in ewes via either the jugular or uterine route protects the CL from PGF2a-induced luteolysis and upregulated cell survival genes such as BCL2-like 1 (BCL2L1, which encodes BCL-xL protein), serine/threonine kinase (AKT), and the X-linked inhibitor of apoptosis (XIAP) in the CL (Antoniazzi et al. 2013). In support, our studies showed that IFNT increases the numbers of viable luteinized granulosa cells (LGCs) as well as myeloid cell leukemia 1 (MCL1), BCL-xL, and XIAP proteins. IFNT also suppresses apoptotic LGC numbers, along with cell death proteins, such as gamma$\mathrm{H} 2 \mathrm{AX}$, cleaved caspase-3, and thrombospondin-2 (THBS2) (Basavaraja et al. 2019).

Transcriptomic analysis of $C L$ at the time of MRP in ewes revealed that pentraxin 3 (PTX3) was higher in the pregnant $\mathrm{CL}$ than in the regressing gland on day 14 (Romero et al. 2013). In addition, in the bovine endometrium, PTX3 was upregulated in the pregnant vs cyclic animals, and these higher levels were maintained throughout implantation and placentation (MansouriAttia et al. 2012). PTX3 is a glycoprotein consisting of eight identical protomers stabilized by interlinked disulfide bonds (Inforzato et al. 2010). In the ovary, PTX3 
was shown to play a key role in the cumulus expansion required for successful ovulation (Varani et al. 2002, Tranguch et al. 2007). It is upregulated in the mural granulosa of mice and cows by LH surge (Varani et al. 2002, Christenson et al. 2013, Shrestha et al. 2015). However, in vitro, PTX3 can only be stimulated in the cumulus oocyte complexes where the presence of oocyte is essential (Salustri et al. 2004). Indeed, it was shown that oocyte-derived paralogs of the TGFB superfamily, namely, GDF9 and BMP15, augment PTX3 in granulosa cells (Varani et al. 2002, Salustri et al. 2004, levoli et al. 2011). Although GDF9 and BMP15 are closely related paralogs, they signal through a discrete kinase domain of activin receptor-like kinase (ALK) and the SMAD2/3 and SMAD1/5/8 pathways, respectively (Moore et al. 2003, Peng et al. 2013).

Whereas the role of PTX3 during ovulation is well established, its role in the CL of early pregnancy and the mode of its induction are presently unknown. This study was designed to investigate the role of IFNT in controlling PTX3 expression in bovine LGCs and its possible actions in regulating IFNT-enhanced LGC survival.

\section{Materials and methods}

Unless otherwise stated, all biochemicals were from SigmaAldrich (Sigma-Aldrich) and the cell culture materials were from Biological Industries (Kibbutz Beit Haemek, Israel).

\section{Isolation and culture of granulosa cells}

We collected bovine ovaries bearing large follicles $(>10 \mathrm{~mm}$ in diameter) from a local slaughterhouse, as described previously (Meidan et al. 1990, Basavaraja et al. 2019). Only follicles containing at least 4 million granulosa cells were included in these experiments. Granulosa cells were enzymatically dispersed and seeded for overnight incubation in DMEM/F-12 containing 3\% fetal calf serum (FCS). The next day, the media was replaced with luteinization media containing FCS (1\%), insulin $(2 \mu \mathrm{g} / \mathrm{mL})$ and forskolin $(10 \mu \mathrm{M}$; Meidan et al. 1990, Basavaraja et al. 2019). Then, the cells were washed with PBS and kept for a 3-5 $\mathrm{h}$ adaptation period in DMEM/F-12 media containing $1 \%$ FCS. Finally, the cells were incubated for the times indicated in the text, either with basal media (containing 1\% FCS; control), recombinant ovine IFNT (rolFNT 0.01-10 $\mathrm{ng} / \mathrm{mL}$; a generous gift from Prof Fuller W. Bazer, Texas A\&M University), recombinant human PTX3 (rhPTX3 60-480 nM; kindly provided by A. Inforzato, Istituto Clinico Humanitas, IRCCS, Rozzano, Italy), $1 \mathrm{ng} / \mathrm{mL}$ of recombinant human TGFB1 (ProSpec-Tany TechnoGene Ltd, Rehovot, Israel), 1 $\mu M$ SB431542 (Pharmacological inhibitor of ALK4, ALK5, and ALK7 kinase activity; Aloysius et al. 2018), or 1-10 $\mu \mathrm{M}$ Dorsomorphin (Pharmacological inhibitor of ALK2, ALK3, and ALK6 kinase activity; (Wertheimer et al. 2018); PeproTech, Rehovot, Israel) or recombinant human THBS1 (rhTHBS1 250 $\mathrm{ng} / \mathrm{mL}$; Genetech, Ingolstadt, Germany). At the end of the incubation period, cells were collected for either total RNA extraction or for flow cytometry, as described subsequently.

\section{Isolation and culture of luteal endothelial cells}

The procedure for cells isolation and enrichment was detailed previously (Levy et al. 2001, Farberov \& Meidan 2016, Basavaraja et al. 2019). Cells from passages 7-10, derived from at least three different $\mathrm{CL}$, were used in the present study. The luteal endothelial cells were seeded in 12-well dishes $(70,000$ cells/well) and cultured overnight in DMEM/F-12 containing $10 \%$ FCS. The next day, the cells were transferred to starvation medium $(0.5 \%$ BSA in $0.1 \%$ FCS $)$ for $24 \mathrm{~h}$. Then the luteal endothelial cells were incubated for $24 \mathrm{~h}$ with or without IFNT ( $1 \mathrm{ng} / \mathrm{mL}$ ). At the end of the incubation period, the total RNA was extracted from the cells.

\section{Experimental animals and synchronization and culture of $C L$ slices}

Experimental animals and synchronization are carried out as described previously (Basavaraja et al. 2019). Briefly, the $\mathrm{CL}$ obtained were cut into slices $(300 \mu \mathrm{m}$ thick, $8 \mathrm{~mm}$ diameter, 10-15 mg wet weight) using a Krumdick Tissue Slicer (K\&F Research, Birmingham, AL, USA) as previously described (Przygrodzka et al. 2014). Then the slices (2 slices/well) were incubated for $12 \mathrm{~h}$ in $\mathrm{M}$-199 supplemented with $0.1 \%$ BSA (ICN Bio Medicals, Inc., Costa Mesa, CA, USA), antibiotics (penicillin-streptomycin; Sigma-Aldrich), and an anti-fungal drug (amphotericin B; Sigma-Aldrich) in the presence or absence of IFNT (1 ng/mL). Afterwards, slices were collected, rapidly frozen in liquid nitrogen and stored at $-80^{\circ} \mathrm{C}$ until total RNA isolation.

\section{Western blot analyses}

Proteins were extracted with a sample buffer, separated by 7.5-12.0\% SDS-PAGE, along with prestained protein ladder (PageRuler plud; product \#26619; Thermo Fisher Scientific) and subsequently transferred to nitrocellulose membranes, as reported previously (Basavaraja et al. 2019). Membranes were cut according to molecular weight, and then all membrane slices were blocked for $1 \mathrm{~h}$ in TBST $(20 \mathrm{mmol} / \mathrm{L}$ Tris, $150 \mathrm{mmol} / \mathrm{L}$ $\mathrm{NaCl}$, and $0.1 \%$ Tween $20 ; \mathrm{pH} 7.6$ ) containing $3 \% \mathrm{BSA}$ or $5 \%$ low-fat milk. Afterwards, each slice was incubated overnight at $4{ }^{\circ} \mathrm{C}$ with the specific antibody. The following antibodies were used: rabbit anti-human PTX3 (1:800; Abcam Cat\# ab190838 RRID:AB_2857343; 41-42 kDa), rabbit anti-human Survivin (1:1000; Abcam Cat\# ab469, RRID:AB_304564; 16-18 kDa), and rabbit anti-p44/42 total mitogen-activated protein kinase (MAPK; 1:1000; Sigma Cat\# ABS44; RRID: AB_11213287). The membranes were then incubated with peroxidase-conjugated goat anti-rabbit IgG (Jackson ImmunoResearch) for $1 \mathrm{~h}$ at room temperature. A chemiluminescent signal was generated with the SuperSignal Detection Kit for horseradish peroxidase (Thermo Fisher Scientific), and the signal was captured with ImageQuant LAS 500 (GE Healthcare Life Sciences). The protein bands were analyzed using Gel-Pro 32 Software (Media Cybernetics, Silver Spring, MD) and the signal of anti-total MAPK (p44/42) antibody was used to correct for protein loading. 


\section{SiRNA transfection}

Initial attempts to transfect luteinized granulosa cells resulted in inconsistent silencing; therefore, granulosa cells were transfected as we published before (Shrestha et al. 2015, Shrestha \& Meidan 2018). These cells were designated cultured granulosa cells.

After their isolation, primary granulosa cells were trypsinized with $0.05 \%$ trypsin and $0.2 \%$ EDTA solution. Trypsinized cells were seeded in 12-well (140,000 cells/well) or 24-well plates (40,000 cells/well) and cultured overnight in DMEM/F-12 medium containing 3\% FCS. The next day, cells were transfected with siRNA (10 nmol/L; GeneCust, Luxembourg, Germany) targeting PTX3 and scrambled siRNA (negative control; 10 nmol/L) using Lipofectamine RNAiMAX (Invitrogen) according to the manufacturer's protocol in 1\% FCS. The siRNA of PTX3 (siPTX3) was sense (S) GGUCAAAGCCACAGAAGUA[dT] [dT], antisense (AS) UACUUCUGUGGCUUUGACC[dT] [dT], corresponding to bases 730-748 of the bovine PTX3 (NM_001076259.2). The sequence of siTHBS1 was sense (S), CUCAGUUACCAUCUGCAAAdTdT, antisense (AS), UUUGCAGAUGGUAACUGAG, corresponding to bases 1176-1194 of the THBS1 (NM_174196.1) (Farberov \& Meidan 2016). The scrambled siRNA sequence - the negative control was (S) UUCUCCGAACGUGUCACGUdTdT and (AS) ACGUGACACGUUCGGAGAAdTdT. At $24 \mathrm{~h}$ posttransfection, cells were incubated with or without IFNT (1 ng/ $\mathrm{mL}$ ) for an additional 24-48 $\mathrm{h}$.

\section{Determination of viable cell numbers}

Viable cell numbers were determined as described previously (Basavaraja et al. 2017, 2019), using the XTT Kit (Biological Industries), which measures the reduction of a tetrazolium component by the mitochondria of viable cells. On the day of measurement, XTT was added to the culture media according to the manufacturer's instructions. Plates were then incubated at $37^{\circ} \mathrm{C}$ for $3-5 \mathrm{~h}$. Afterwards, the absorbance was read at 450 $\mathrm{nm}$ (reference absorbance, $630 \mathrm{~nm}$ ).

\section{Cell cycle assay}

Twenty-four hours post-transfection (with either scrambled siRNA or PTX3 siRNA), the cells were incubated for an additional $24 \mathrm{~h}$ with or without IFNT $(1 \mathrm{ng} / \mathrm{mL})$. Then cells were collected with trypsin, washed once with PBS and fixed for $30 \mathrm{~min}$ at $40^{\circ} \mathrm{C}$ with $70 \%$ ethanol. Next, cells were washed with PBS and incubated with propidium iodide (PI; $1 \mathrm{mg} / \mathrm{mL}$ ) for $30 \mathrm{~min}$ in the dark. At least 10,000 events were recorded to determine the phrasing DNA content and the cell cycle distribution of the cells using flow cytometry (CytoFlex; Beckman Coulter). Data were analyzed using Flowjo software.

\section{RNA extraction and quantitative real-time PCR}

Total RNA was isolated using Tri-Reagent (Molecular Research Center) according to the manufacturer's instructions. Total RNA $(1 \mu \mathrm{g})$ was reverse transcribed. Real-time PCR was performed using the LightCycler 96 system (Roche Diagnostics) with LightCycler 480 SYBR Green I Master (Roche Diagnostics) (Shrestha \& Meidan 2018, Basavaraja et al. 2019). Table 1 lists the sequences of primers used for quantitative qPCR. All primers were designed to span an intron to prevent amplification of genomic DNA and have single-product melting curves, as well as consistent amplification efficiencies between 1.8 and 2.2 (Schmittgen \& Livak 2008, Kfir et al. 2018, Shrestha \& Meidan 2018, Basavaraja et al. 2019). To select the most stable housekeeping gene, we applied the NormFinder algorithm; we selected GAPDH as a housekeeping gene, as described previously (Basavaraja et al. 2017, Kfir et al. 2018). The threshold cycle number $(\mathrm{Ct})$ was used to quantify the relative abundance of the gene; arbitrary units were calculated as $2-\Delta \mathrm{Ct}=2-(\mathrm{Ct}$ target gene $-\mathrm{Ct}$ housekeeping gene) (Livak \& Schmittgen 2001).

\section{Statistical analyses}

All statistical analyses were performed using GraphPad Prism version 6.01 Software (GraphPad Software, Inc.). Data are presented as means \pm S.E.M. Cell culture experiments comprised at least three independent repeats; each repeat consisted of cells obtained from different follicles (one follicle/cow). CL slices were collected from four different mid-luteal phase (days 12-14 of the estrous cycle) cows. Data were analyzed by either Student's t-test or ANOVA, followed by Bonferroni's post hoc multiple comparison test, when indicated. In all analyses, a value of $P \leq 0.05$ was considered significant.

Table 1 Gene names, sequences of primers or TaqMan Assays ID and Gene Bank accession numbers, used for real-time PCR performed in luteal cells and CL slices.

\begin{tabular}{|c|c|c|c|c|}
\hline \multirow[b]{2}{*}{ Gene name } & \multicolumn{2}{|c|}{ Sequence $\left(5^{\prime}-3^{\prime}\right)$} & \multirow[b]{2}{*}{ TaqMan Assay ID } & \multirow[b]{2}{*}{ Accession No. } \\
\hline & Forward & Reverse & & \\
\hline GAPDH & gtcttcactaccatggagaagg & tcatggatgaccttggccag & & NM_001034034 \\
\hline PTX3 & aacagactggtcgctgatgct & tcccaggtgctgcacagat & & NM_001076259.2 \\
\hline SERPINE1 & cagaaggtgaagattgaggtg & ggcccatgaacaggacagttcc & & NM_174137 \\
\hline BIRC5 & caaagaaagtccgctgtgc & ggtgtgccctggaаacgac & & NM_001001855.3 \\
\hline$X I A P$ & acccaaggaaccctgtcatgtgt & cgcctgtgttctgaccacgc & & NM_001205592.1 \\
\hline FASL & gaggagggaccacaacacag & tggactctctgagttcagcc & & NM_001098859.2 \\
\hline THBS1 & atcatggctgactcaggac & taagcccatggttccagaa & & NM_174196.1 \\
\hline GAPDH & & & Bt03210919_g1 & NM_001034034 \\
\hline PTX3 & & & Bt03249012_m1 & NM_001076259.2 \\
\hline
\end{tabular}




\section{Results}

\section{IFNT induces PTX3 in luteal cells}

IFNT dose-dependently stimulated PTX3 mRNA and protein in bovine LGCs (Fig. 1). PTX3 was also stimulated by IFNT in two other luteal models that we employed before (Basavaraja et al. 2017): luteal endothelial cells and mid-cycle $\mathrm{CL}$ slices. In both, $1 \mathrm{ng} / \mathrm{mL}$ of IFNT significantly augmented PTX3: more than 2-fold in luteal endothelial cells and 1.4-fold in CL slices after 12 $\mathrm{h}$ incubation (the longest period for which these slices maintained their viability (Fig. 2A and B) (Basavaraja et al. 2017). LGCs were the cell type most responsive to IFNT $(1 \mathrm{ng} / \mathrm{mL})$ in terms of PTX3 (14-fold, compared with 2 and 1.4 in luteal endothelial cells and CL slices, respectively). In addition, these cells are highly sensitive and even a low dose of IFNT $(0.01 \mathrm{ng} / \mathrm{mL})$ resulted in a significant increase in PTX3 expression $(\sim 5$-fold; $P<0.01 ;$ Fig. 1).

\section{IFNT increased PTX3 via an ALK 2/3/6-dependent pathway in LGCS}

To gain further understanding of the mechanism involved in IFNT-stimulated PTX3, we employed commonly used pharmacological inhibitors of ALK-dependent pathways as a tool to suppress downstream SMAD

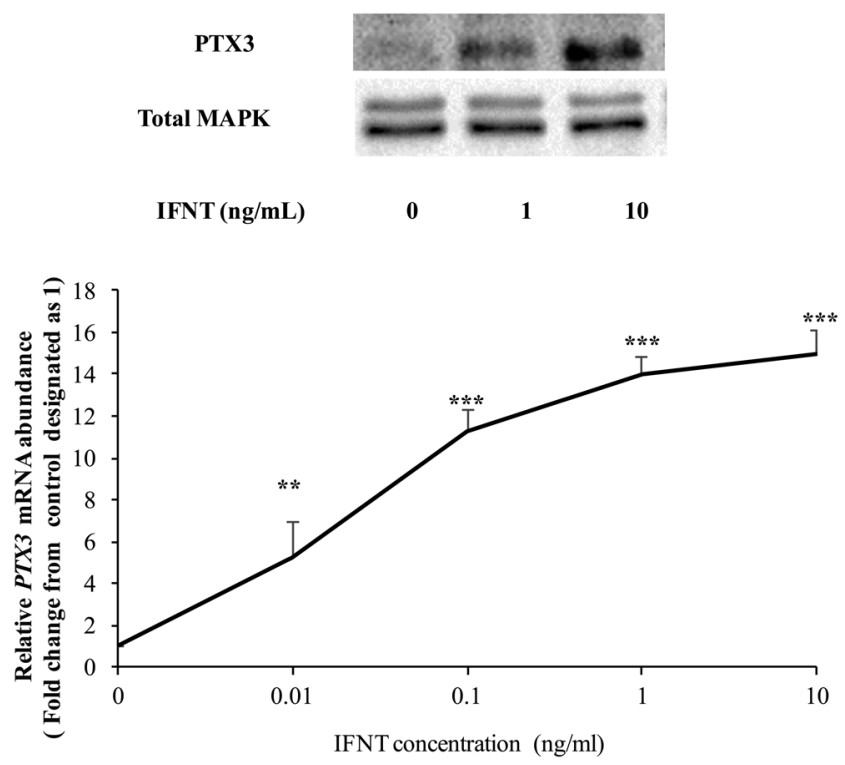

Figure 1 Dose-dependent stimulation of PTX3 by IFNT in LGCs. Cells were incubated for $24 \mathrm{~h}$ with basal media $(0 \mathrm{ng} / \mathrm{mL})$ or varying the concentrations of rolFNT. Upper panel: PTX3 protein was determined in cell extracts by Western blotting and normalized to relative abundance of total MAPK (p44/42); a representative image is shown. Lower panel: PTX3 mRNA. Cells were harvested after $24 \mathrm{~h}$ and mRNA levels were determined using qPCR. The results represent the means \pm S.E.M. of four independent experiments. Asterisks indicate significant $\left({ }^{* *} P<0.01\right.$ and $\left.{ }^{* * *} P<0.001\right)$ statistical differences from the control $(0 \mathrm{ng} / \mathrm{mL})$.
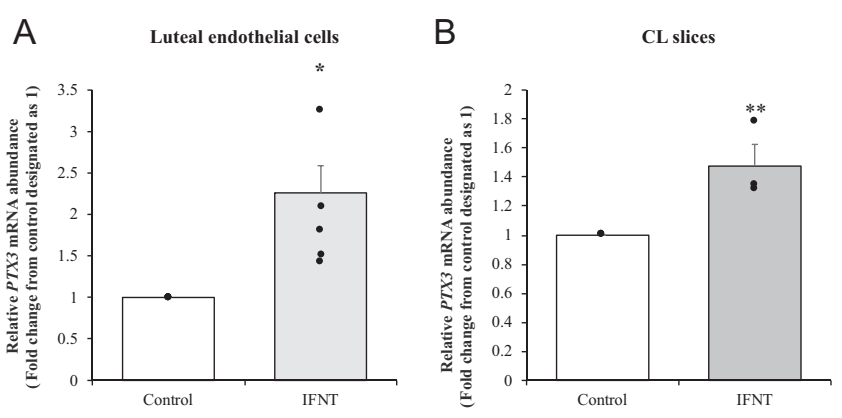

Figure 2 IFNT elevated PTX3 mRNA levels in luteal endothelial cells and in $\mathrm{CL}$ slices. Luteal endothelial cells $(\mathrm{A} ; 24 \mathrm{~h})$ and $\mathrm{CL}$ slices (B; $12 \mathrm{~h}$ ) were incubated with either basal medium alone (control) or with IFNT (1 ng/mL). PTX3 mRNA levels were determined using qPCR. The results represent the means \pm S.E.M. of four independent experiments. The asterisk denotes significant differences from their respective control group $\left({ }^{*} P<0.05\right)$.

phosphorylation (Aloysius et al. 2018, Wertheimer et al. 2018). SB431542 and dorsomorphin were shown to inhibit the kinase activity of ALK4, ALK5, and ALK7 (the receptors that phosphorylate SMAD2/3), and of ALK2, ALK3, and ALK6 (the receptors that phosphorylate SMAD1/5/8), respectively (Aloysius et al. 2018, Wertheimer et al. 2018). SB431542 (1 $\mu \mathrm{M})$ had no effect on basal, IFNT, or TGFB1-induced PTX3 (Fig. 3A). As a positive control, we measured a classical TGFB1 downstream target gene, SERPINE1; its expression was indeed abolished by SB431542 under basal level and TGFB1-stimulated conditions, indicating that the TGFB1 pathway in these cells is functional (data not shown). Then, we examined the effect of dorsomorphin, used as ALK2/3/6 receptor inhibitor. Cells were incubated in the presence or absence of IFNT $(1 \mathrm{ng} / \mathrm{mL})$ and with different doses $(1-10 \mu \mathrm{M})$ of dorsomorphin. As shown in Fig. 3C, dorsomorphin produced a significant dosedependent inhibition of IFNT-induced PTX3 in these cells (Fig. 3B). Dorsomorphin also significantly reduced basal PTX3 levels at 5uM.

\section{PTX3 affected basal and IFNT-induced prosurvial activities in LGCs}

Our previous work indicated that IFNT promotes LGC survival and improves its ability to withstand apoptotic signals (Basavaraja et al. 2019). This conclusion was further substantiated here by demonstrating that $1 \mathrm{ng} / \mathrm{mL}$ of IFNT elevated the mRNA levels of the key mediators of cell health, that is, a baculoviral IAP repeat containing 5 (BIRC5; encoding survivin protein; Fig. 4A) and XIAP (Fig. 4C). Concomitantly, IFNT significantly decreased the expression of Fas ligand, a death-inducing signal (FASL; Fig. 4B). Next, we explored whether PTX3 may play a role in LGC survival. First, various doses of rhPTX3 (60-480 nM) were added to the culture media and viable cell numbers were measured. As shown in Fig. 5, 
A

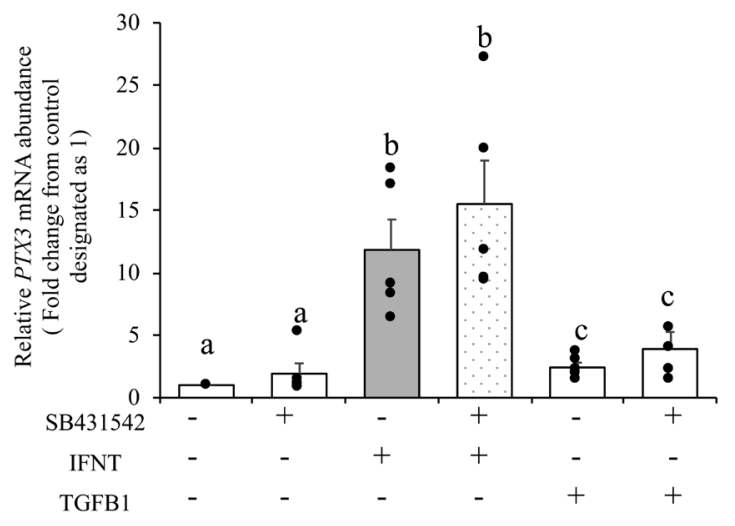

B

$$
\text { B }
$$

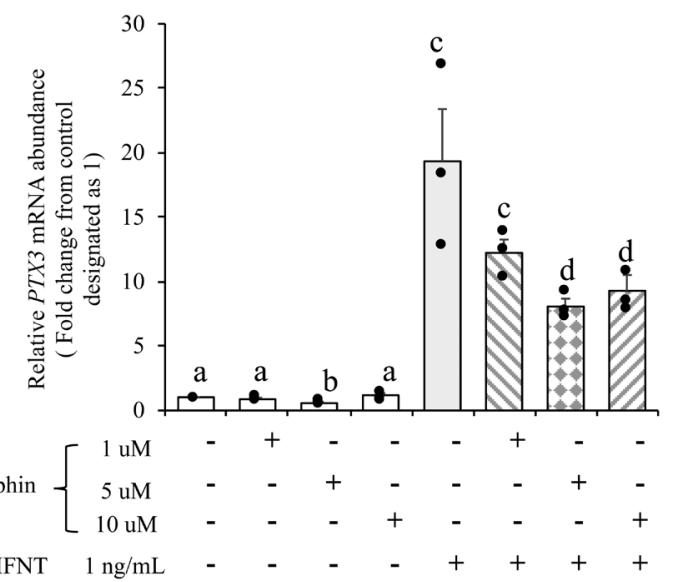

Figure 3 ALK 2/3/6 but not ALK 4/5/7 inhibition modulates IFNTinduced PTX3 expression in bovine LGCs. (A) Cells were incubated with either basal media (control) or with TGFB1 receptor inhibitor (SB431542, $10 \mu \mathrm{M})$, IFNT (1 ng/mL), recombinant human TGFB1 (1 $\mathrm{ng} / \mathrm{mL}$ ), or with their combination for $24 \mathrm{~h}$. (B) Cells were treated with basal media, dorsomorphin $(1-10 \mu \mathrm{M})$, IFNT $(1 \mathrm{ng} / \mathrm{mL})$, or with their combination for $24 \mathrm{~h}$. The mRNA levels of PTX3 were determined using qPCR. The results are expressed as the mean \pm S.E.M. of four independent experiments. The different letters indicate significant statistical differences at $P<0.05$ analyzed using two-way ANOVA, followed by Bonferroni's post hoc multiple comparison test.

rhPTX3 produced a modest, dose-dependent increase in viable cells; a $120 \mathrm{nM}$ dose resulted in a maximal effect (1.32-fold; $P<0.02$; Fig. 5). Because PTX3 is highly expressed in bovine LGCs, we next examined the impact of lowering endogenous PTX3 by using siRNA silencing. These studies also served to examine the involvement of PTX3 in IFNT actions. PTX3 silencing was carried out in cells that were not previously exposed to forskolin plus insulin (luteinization medium); however, their response to IFNT in terms of PTX3, XIAP, BIRC5, and FASL was highly comparable, both in trends and magnitude. This may not be surprising because we used granulosa cells derived from large follicles, which are prone to be luteinized in culture. In addition, they were cultured for 2-4 days with FCS, which is known to promote
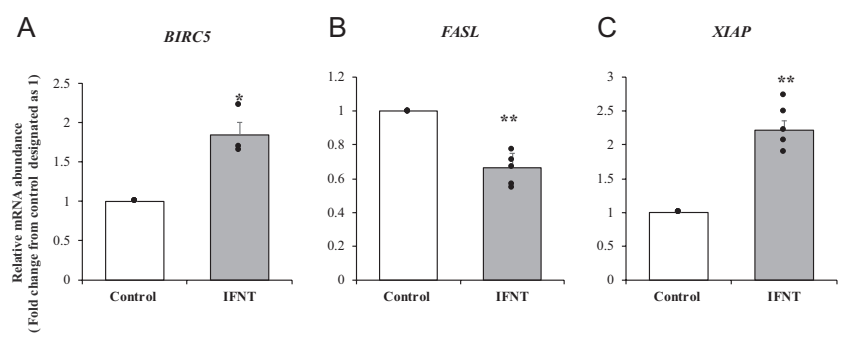

Figure 4 IFNT inversely affects BIRC5, FASL, and XIAP in LGCs. Cells were incubated with basal media (control; $0 \mathrm{ng} / \mathrm{mL}$ ) or with rolFNT (1 ng/mL) for $24 \mathrm{~h}$. (A) BIRC5 mRNA, (B) FASL, and (C) XIAP mRNA expression levels were measured by $q P C R$. The results represent the means \pm S.E.M. of four independent experiments. Asterisks denote significant $\left({ }^{*} P<0.05\right.$ and $\left.{ }^{*} * P<0.01\right)$ differences from their respective controls.

luteinization. The data in Fig. 6A show that PTX3 siRNA significantly abolished basal and IFNT-induced PTX3 (by $\sim 70 \%$ ), compared to cells transfected with scrambled siRNA. The upper panel shows that PTX3 protein levels were also abolished in cells transfected with PTX3 siRNA, regardless of IFNT treatment, testifying to the efficacy of PTX3 silencing. Ablating endogenous PTX3 was accompanied by a significant reduction of viable cultured granulosa cells, compared with control cells (cells transfected with scrambled siRNA; NC, Fig. 6B), demonstrating its role in normal cell health. Importantly, in silenced PTX3 cells, IFNT could no longer promote cell viability (Fig. 6B), implying that PTX3 is involved in the IFNT-elevated survival of cultured granulosa cells. The effect of PTX3 silencing on the progression of the cell cycle was then determined using PI staining and flow cytometry. As shown in Table 2, the cytometric analysis showed that IFNT significantly elevates the percentage of cells in S-phase (proliferating cells, $8.14 \pm 0.40$ $\%$ vs basal $5.83 \pm 0.53 \%, P<0.05)$. However, this effect could not be observed in PTX3-silenced cells

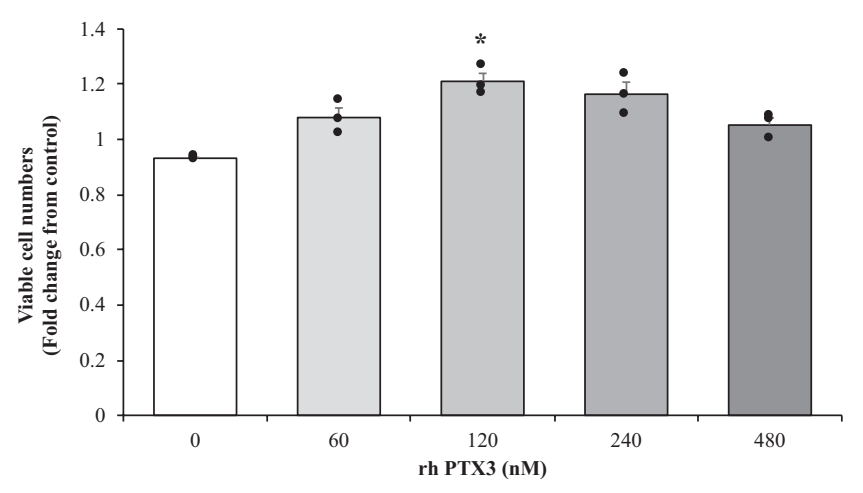

Figure 5 Recombinant human PTX3 elevates viable LGCs numbers. Cells were treated with basal media $(0 \mathrm{nM}$; control) or with various doses of hPTX3 (60-480 nM) for $48 \mathrm{~h}$. Cell viability was determined using the XTT assay. The results are expressed as the mean \pm S.E.M. of four independent experiments. The asterisk denotes a significant $\left({ }^{*} P<0.05\right)$ difference from the control $(0 \mathrm{nM})$. 


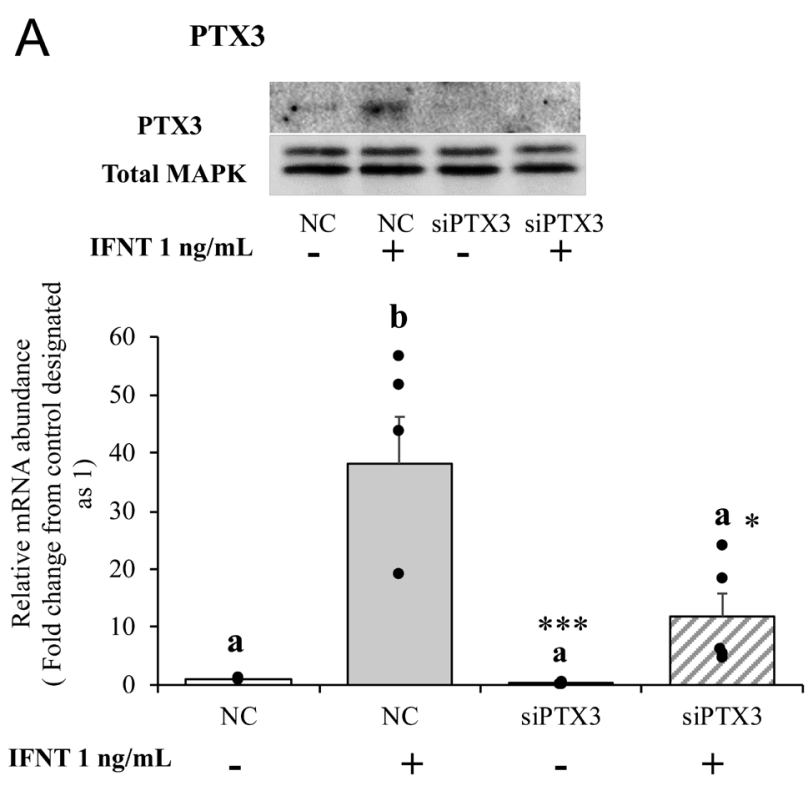

B XTT

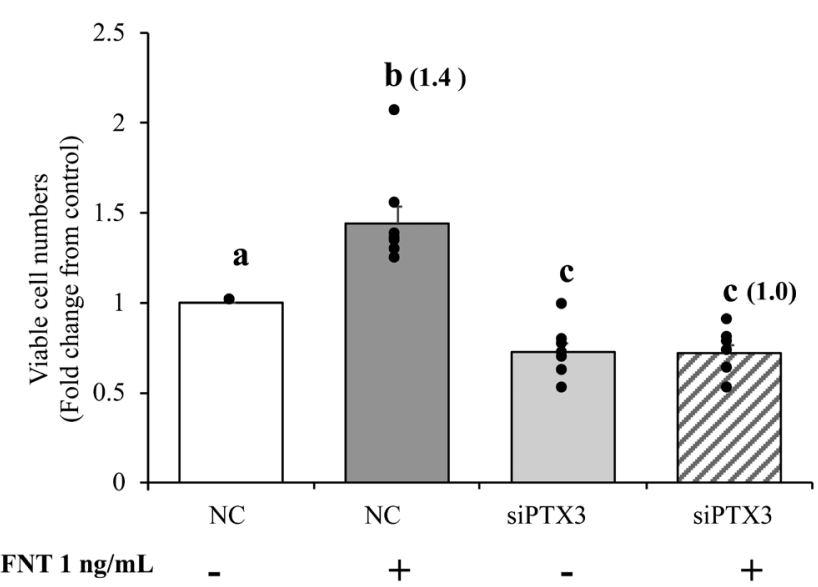

Figure 6 PTX3 silencing decreases IFNT-induced viability of LGCs. Cells were transfected with $10 \mathrm{nM}$ of scrambled siRNA (siNC) or specific PTX3 siRNA (siPTX3) for 18-20 h, followed by incubation with IFNT ( $1 \mathrm{ng} / \mathrm{mL}$ ) or without (basal) for an additional $24 \mathrm{~h}$ (for RNA) or $48 \mathrm{~h}$ (for cell viability). (A) PTX3 expression - upper panel: PTX3 protein was determined in cell extracts by Western blotting and was normalized relative to the abundance of total MAPK (p44/42); a representative image is shown. Lower panel: PTX3 mRNA. (B) Cell viability was determined using XTT. The results are presented as the means \pm S.E.M. from eight independent experiments. The number in parenthesis indicates the fold change of IFNT treatment from respective control. The asterisk denotes a significant $(* P<0.05)$ difference from the siNC. The different letters indicate significant statistical differences at $P<0.05$ analyzed using two-way ANOVA, followed by Bonferroni's post hoc multiple comparison test.

$(6.05 \pm 0.62 \%$ vs $5.39 \pm 0.93 \%$ ns). The effect of silencing and IFNT were less robust for cell cycle data because of the shorter incubation time $24 \mathrm{~h}$ (instead of 48h in Fig. 6B). The data presented in Fig. $7 \mathrm{~A}$ and $\mathrm{B}$ are in line with those shown in Fig. 4 and further support
Table 2 Cytometric analysis of the cell cycle: the percentage of S-phase cells. Data are presented as mean \pm S.E.M. Granulosa cells were transfected with either scrambled siRNA or PTX3-specific siRNA and treated with IFNT for $24 \mathrm{~h}(1 \mathrm{ng} / \mathrm{mL})$. Post-treatment cells were stained with PI and cell cycle phases were analyzed by flow cytometry using Flowjo software. Cells were obtained from three separate follicles.

\begin{tabular}{lc}
\hline Treatment & Percent of cells in S-phase \\
\hline Scrambled siRNA & $5.83 \pm 0.53^{\mathrm{a}}$ \\
Scrambled siRNA+ IFNT & $8.14 \pm 0.40^{\mathrm{b}}$ \\
PTX3 siRNA & $5.39 \pm 0.93^{\mathrm{a}}$ \\
PTX3 siRNA+IFNT & $6.05 \pm 0.62^{\mathrm{a}}$ \\
\hline
\end{tabular}

a,b Different letters indicate significant differences $(P<0.05)$ between the groups analysis based on Student's t-test.

the notion that PTX3 is involved in the regulation of cell viability. The silencing of PTX3 in cultured granulosa cells not only reduces the basal levels of BIRC5 and its survivin protein levels - it also suppresses both the mRNA and protein levels elevated by IFNT, rendering the effect of IFNT non-significant (Fig. 7A; upper and lower panels). Furthermore, FASL, known to induce apoptosis, showed an inverse response to IFNT in scrambled (NC) vs PTX3-silenced cells. The inhibitory effect of IFNT on NC-transfected cells (Fig. 7B) or non-transfected cells (Fig. 4B) was not maintained in PTX3-silenced cells, rather IFNT further stimulated FASL, reaching their highest levels (Fig. 7B). Unlike BIRC5 and FASL, XIAP expression, although induced by IFNT, was not affected by PTX3 silencing (Fig. 7C), demonstrating the specificity of IFNT actions. Interestingly, PTX3 and THBS1, a known luteal proapoptotic factor, (Farberov \& Meidan 2016, Farberov et al. 2019) appear to be mutually inhibitory because PTX3 silencing elevated THBS1, and vice versa, THBS1 silencing resulted in higher PTX3 expression (Fig. 8A and B). The latter is further supported by the finding that exogenous rhTHBS1 $(250 \mathrm{ng} / \mathrm{mL})$ reduced PTX3 expression (Fig. 8B).

\section{Discussion}

The findings of this study revealed that PTX3 is highly stimulated by IFNT in various bovine luteal in vitro models. The mechanism involved in IFNT-induced PTX3 is dependent on ALK 2/3/6 activating SMAD1/5/8 phosphorylation. Importantly, this study demonstrated that PTX3 is necessary to maintain the survival of bovine LGCs; it also mediated the proliferative, anti-apoptotic actions of IFNT. These actions include modulation of genes related to cell health, such as BIRC5, FASL and THBS1.

The fact that PTX3 was shown here to be an IFNT responsive gene is supported by a previously published article showing that in vitro exposure of bovine endometrial cells to IFNT results in upregulated PTX3 (Mansouri-Attia et al. 2012). Induction of PTX3 by IFNT in LGCs was robust and highly sensitive. Like PTX3, 
A

\section{BIRC5/survivin}


B



C

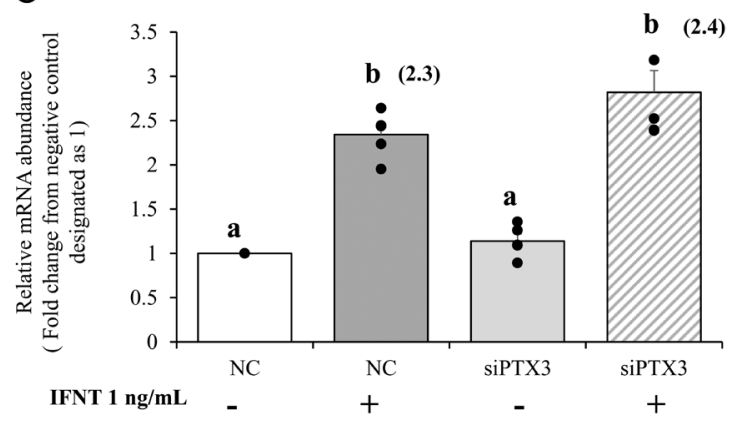

Figure 7 Effect of PTX3 silencing on IFNT-regulated BIRC5, FASL, and $X I A P$ mRNA. Cells were transfected either with $10 \mathrm{nM}$ of scrambled siRNA (negative control (siNC)) or specific PTX3 siRNA (siPTX3) for $18-20 \mathrm{~h}$, followed by incubation with IFNT $(1 \mathrm{ng} / \mathrm{mL})$, or without (basal) for an additional $24 \mathrm{~h}$. (A) Upper panel, representative image of survivin protein determined in cell extracts by Western blotting and normalized relative to the abundance of total MAPK (p44/42); The lower panel shows BIRC5 mRNA; (B) FASL mRNA; (C) XIAP mRNA. mRNA levels were determined using $\mathrm{qPCR}$. The results are presented as the means \pm S.E.M. from four to five independent experiments. The asterisk denotes a significant $\left({ }^{*} P<0.05\right)$ difference from the siNC. The number in parenthesis indicates the fold change of IFNT treatment from respective control. The different letters indicate significant statistical differences at $P<0.05$ analyzed using two-way ANOVA, followed by Bonferroni's imultiple comparison test.
A THBS1



B
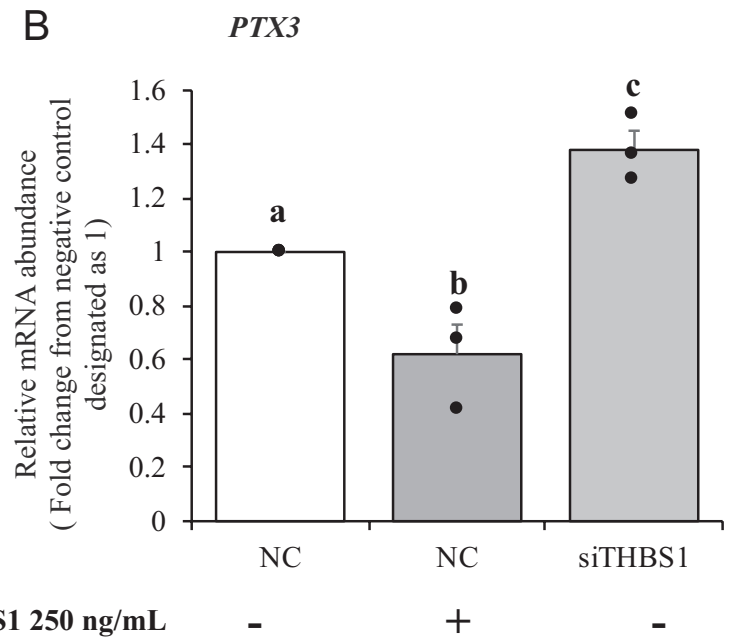

THBS1 $250 \mathrm{ng} / \mathrm{mL}$

Figure 8 Reciprocal inhibition of THBS1 and PTX3 expression in LGCs. (A) Cells were transfected with $10 \mathrm{nM}$ of scrambled siRNA (siNC) or specific PTX3 siRNA (siPTX3) or specific THBS1 siRNA (siTHBS1). At $48 \mathrm{~h}$ post-transfection, the cells were harvested for determination of THBS1 mRNA using qPCR. (B) Cells were transfected with $10 \mathrm{nM}$ of siNC or specific siTHBS1 for 18-20 h, followed by incubation in basal media or with rhTHBS1 $(250 \mathrm{ng} / \mathrm{mL})$ for an additional $24 \mathrm{~h}$. At the end of incubation, the cells were harvested for determination of PTX3 mRNA using qPCR. The results are presented as the means \pm S.E.M. from three to four independent experiments. The different letters indicate significant statistical differences at $P<0.05$ analyzed using one (A) or two-way (B) ANOVA, followed by Bonferroni's post hoc multiple comparison test.

the ISGs response to IFNT in LGCs was more sensitive by several orders of magnitude than that of luteal endothelial cells and CL slices (Basavaraja et al. 2017, 2019). There were higher total STAT1 levels $(\sim 5-$ and $\sim 9$-fold for protein and mRNA, respectively) as well as higher IFNT-induced phosphorylated STAT1 levels in LGCs (145-fold at $45 \mathrm{~min}$ ), compared with 25 -fold at 45 min in luteal endothelial cells (Basavaraja et al. 2017, 2019). These findings suggest that STAT1 may be the upstream regulator of not only ISGs, but also for PTX3. Additionally, these data further support the idea that 
LGCs constitute the major cell type involved in IFNT actions in $\mathrm{CL}$.

PTX3 was shown to be modulated in granulosa cells by various members of the TGFB superfamily acting via different signaling pathways. For instance, GDF9 and activin A upregulated PTX3 in a cultured mouse cumulus-oocyte complex acting via a classical TGFB1 pathway,that is, SMAD 2/3 signaling (Dragovic et al. 2007). In contrast, another study carried out in human granulosa cells showed that SMAD2/3 signaling mediates the TGFB1 and activin A-induced suppression of PTX3 (Li et al. 2018, Liu et al. 2019). Our study showed that in bovine LGCs, TGFB1 only slightly stimulated PTX3 and that SB431542 had no effect on this action. Instead, our findings suggest that ALK 2/3/6 receptors, inhibited by dorsomorphin, are involved in IFNT-induced PTX3 in these cells. These receptors are known to mediate SMAD1/5/8 phosphorylation (Yu et al. 2008). Since IFNT cannot directly activate this pathway, it is postulated that another molecule may be involved in activating these receptors in LGCs. Since ALK 2/3/6-dependent SMAD1/5/8 phosphorylation serves as a canonical pathway for BMPs and AMH (Shimasaki et al. 2004) and both are expressed in granulosa cells of various species (Pierre et al. 2016, Reader et al. 2016, Rajesh et al. 2018), we propose that one of these molecules is elevated by IFNT. However, this proposition requires further research.

Previously, we showed that IFNT acts as a survival factor for both bovine luteal endothelial and LGC cells. In the latter, IFNT induces cell viability, prosurvival proteins (MCL1, BCL-XL, and XIAP) and inhibits proapoptotic factors (gamma-H2AX, THBS2, and cleaved caspase-3) (Basavaraja et al. 2017, 2019). PTX3 is also produced by various cancer cell types where it is correlated with tumor progression (Yeh et al. 2019). Recent studies in cervical, head and neck, glioma, and epithelial-hepatocellular carcinoma portray PTX3 as a pro-oncogene associated with enhanced proliferation, invasion, and metastasis (Chang et al. 2015, Ying et al. 2016, Song et al. 2018).

This study extends our knowledge about the role of IFNT in LGC survival, demonstrating that IFNT induces BIRC5 (a gene encoding survivin protein) and $X I A P$, while decreasing FASL. Furthermore, the results indicate that PTX3 is a key mediator of these actions. In fact, rhPTX3 alone increased LGC viability; however, this response was modest probably because of species incompatibility, especially in the unique $\mathrm{N}$-terminal region important for its biological activity (Leali et al. 2009). Instead, the approach of silencing endogenous levels with siRNA provided us with a robust experimental tool to illustrate the proliferative actions of PTX3. The silencing of PTX3 per se reduced LGCs viability and proliferation; additionally, it affected key genes related to cell health. Furthermore, the silencing of PTX3 reversed IFNT-dependent effects on cell viability, BIRC5/survivin and FASL, which is consistent with the idea that the proliferative actions of IFNT were dependent on PTX3.

Besides BIRC5 and FASL mentioned previously, PTX3 silencing increased THBS1. THBS1 is one of the major proapoptotic and antiangiogenic protein induced during luteolysis by PGF2a (Farberov et al. 2019). Previously, we have showen that IFNT downregulated THBS1 in bovine CL slices and luteal endothelial cells (Basavaraja et al. 2017). Moreover, IFNT also reversed the apoptotic actions of THBS1 on viable LGCs numbers, XIAP, and cleaved caspase-3 (Basavaraja et al. 2019). In LGCs, we show here that ablating THBS1 induced PTX3 and vice versa, suggesting an interplay between these two factors and additional support for their apoptotic and survival actions, respectively. Survivin is a member of the inhibitor of apoptosis proteins (IAPs) family, which can regulate both cell proliferation and apoptotic cell death. However, it has no enzymatic activity of its own; instead, it achieves most of its tasks in association with other proteins. For example, it cooperates with XIAP (also induced by IFNT in LGCs and CL. Survivin, shown here to be induced by IFNT in PTX3 dependent manner, affects XIAP interaction with caspases (Wheatley \& Altieri 2019). Survivin also affects cell proliferation, since it is a part of the chromosomal passenger complex (CPC) family, which plays a role in the separation of sister chromatids cytokinesis, and microtubule stability during mitosis (Wheatley et al. 2001, 2007, Carvalho et al. 2003, Lens et al. 2003).

Contrary to BIRC5, IFNT suppresses FASL and PTX3 silencing reverses this effect. Fas and FASL are members of the tumor necrosis factor (TNF)-receptor and TNF families, respectively. The interaction of FAS receptor with FASL results in activating a caspase cascade that initiates apoptosis (Ashkenazi \& Dixit 1998, Volpe et al. 2016). In agreement with their functions in apoptosis, FAS and FASL were shown to be elevated in bovine granulosa cells during atresia and luteolysis (Porter et al. 2001, Sinderewicz et al. 2017). In fact, PGF2a was specifically shown to upregulate both FAS and FASL in $\mathrm{CL}$ undergoing regression in several species (Yadav et al. 2005, Przygrodzka et al. 2015). FASL adds to the list of transcripts in the $\mathrm{CL}$ that are inversely regulated by PGF2a and IFNT. So far, it includes XIAP, THBS1, TGFB1, SERPINE1, EDN1, and BCL-xL (Romero et al. 2013, Basavaraja et al. 2017, 2019). The fact that IFNT and the luteolytic hormone, PGF2a inversely affect luteal genes testifies to the physiological importance of IFNT actions in the CL.

The findings reported here suggest that PTX3 is a novel luteal prosurvival factor that mediates IFNT actions. Together with our previous studies (Basavaraja et al. 2017, 2019), they suggest that IFNT employs diverse mechanisms to increase viable cells and to decrease apoptotic cells, in order to maintain CL function in domestic ruminants during early pregnancy. 


\section{Declaration of interest}

The authors declare that there is no conflict of interest that could be perceived as prejudicing the impartiality of the research reported.

\section{Funding}

This work was supported by a grant from BARD (Binational Agricultural Research \& Development Fund - IS-4799-15).

\section{Author contribution statement}

R M and R B designed the study. R B, S T M and K S conducted and analyzed luteal cell culture experiments and analysis of the data. The $C L$ slices experiment were designed and conducted by M M K, R B and E P. R B and R M wrote the paper. All other authors reviewed, corrected and approved the final manuscript.

\section{References}

Aloysius A, DasGupta R \& Dhawan J 2018 The transcription factor Lef1 switches partners from beta-catenin to Smad3 during muscle stem cell quiescence. Science Signaling 11 eaan3000. (https://doi.org/10.1126/ scisignal.aan3000)

Antoniazzi AQ, Webb BT, Romero JJ, Ashley RL, Smirnova NP, Henkes LE, Bott RC, Oliveira JF, Niswender GD, Bazer FW et al. 2013 Endocrine delivery of interferon tau protects the corpus luteum from prostaglandin F2 alpha-induced luteolysis in ewes. Biology of Reproduction $\mathbf{8 8} 144$. (https://doi.org/10.1095/biolreprod.112.105684)

Ashkenazi A \& Dixit VM 1998 Death receptors: signaling and modulation. Science 281 1305-1308. (https://doi.org/10.1126/ science.281.5381.1305)

Basavaraja R, Przygrodzka E, Pawlinski B, Gajewski Z, Kaczmarek MM \& Meidan R 2017 Interferon-tau promotes luteal endothelial cell survival and inhibits specific luteolytic genes in bovine corpus luteum. Reproduction 154 559-568. (https://doi.org/10.1530/REP-17-0290)

Basavaraja R, Madusanka ST, Drum JN, Shrestha K, Farberov S, Wiltbank MC, Sartori R \& Meidan R 2019 Interferon-tau exerts direct prosurvival and antiapoptotic actions in luteinized bovine granulosa cells. Scientific Reports 9 14682. (https://doi.org/10.1038/s41598-01951152-6)

Bazer FW \& Thatcher WW 2017 Chronicling the discovery of interferon tau. Reproduction 154 F11-F20. (https://doi.org/10.1530/REP-17-0257)

Carvalho A, Carmena M, Sambade C, Earnshaw WC \& Wheatley SP 2003. Survivin is required for stable checkpoint activation in taxol-treated HeLa cells. Journal of Cell Science 116 2987-2998. (https://doi.org/10.1242/ jcs.00612)

Chang WC, Wu SL, Huang WC, Hsu JY, Chan SH, Wang JM, Tsai JP \& Chen BK 2015 PTX3 gene activation in EGF-induced head and neck cancer cell metastasis. Oncotarget 6 7741-7757. (https://doi. org/10.18632/oncotarget.3482)

Christenson LK, Gunewardena S, Hong X, Spitschak M, Baufeld A \& Vanselow J 2013 Research resource: preovulatory LH surge effects on follicular theca and granulosa transcriptomes. Molecular Endocrinology 27 1153-1171. (https://doi.org/10.1210/me.2013-1093)

DeMayo FJ \& Lydon JP 202090 YEARS OF PROGESTERONE: New insights into progesterone receptor signaling in the endometrium required for embryo implantation. Journal of Molecular Endocrinology 65 T1-T14. (https://doi.org/10.1530/JME-19-0212)

Devoto L, Kohen P, Munoz A \& Strauss 3rd JF 2009 Human corpus luteum physiology and the luteal-phase dysfunction associated with ovarian stimulation. Reproductive Biomedicine Online 18 (Supplement 2) 19-24. (https://doi.org/10.1016/s1472-6483(10)60444-0)

Dragovic RA, Ritter LJ, Schulz SJ, Amato F, Thompson JG, Armstrong DT \& Gilchrist RB 2007 Oocyte-secreted factor activation of SMAD
2/3 signaling enables initiation of mouse cumulus cell expansion. Biology of Reproduction 76 848-857. (https://doi.org/10.1095/ biolreprod.106.057471)

Farberov S \& Meidan R 2016 Thrombospondin-1 affects bovine luteal function via transforming growth factor-beta1-dependent and independent actions. Biology of Reproduction 94 25. (https://doi. org/10.1095/biolreprod.115.135822)

Farberov S, Basavaraja R \& Meidan R 2019 Thrombospondin-1 at the crossroads of corpus luteum fate decisions. Reproduction 157 R73-R83. (https://doi.org/10.1530/REP-18-0530)

levoli E, Lindstedt R, Inforzato A, Camaioni A, Palone F, Day AJ, Mantovani A, Salvatori G \& Salustri A 2011 Implication of the oligomeric state of the N-terminal PTX3 domain in cumulus matrix assembly. Matrix Biology 30 330-337. (https://doi.org/10.1016/j.matbio.2011.05.002)

Inforzato A, Baldock C, Jowitt TA, Holmes DF, Lindstedt R, Marcellini M, Rivieccio V, Briggs DC, Kadler KE, Verdoliva A et al. 2010 The angiogenic inhibitor long pentraxin PTX3 forms an asymmetric octamer with two binding sites for FGF2. Journal of Biological Chemistry 285 17681-17692. (https://doi.org/10.1074/jbc.M109.085639)

Kfir S, Basavaraja R, Wigoda N, Ben-Dor S, Orr I \& Meidan R 2018 Genomic profiling of bovine corpus luteum maturation. PLOS ONE 13 e0194456. (https://doi.org/10.1371/journal.pone.0194456)

Leali D, Alessi P, Coltrini D, Rusnati M, Zetta L \& Presta M 2009 Fibroblast growth factor-2 antagonist and antiangiogenic activity of long-PENTRAXIN 3-derived synthetic peptides. Current Pharmaceutical Design 15 3577-3589. (https://doi.org/10.2174/138161209789206962)

Lens SM, Wolthuis RM, Klompmaker R, Kauw J, Agami R, Brummelkamp T, Kops G \& Medema RH 2003 Survivin is required for a sustained spindle checkpoint arrest in response to lack of tension. EMBO Journal 22 2934-2947. (https://doi.org/10.1093/emboj/cdg307)

Levy N, Gordin M, Mamluk R, Yanagisawa M, Smith MF, Hampton JH \& Meidan R 2001 Distinct cellular localization and regulation of endothelin-1 and endothelin-converting enzyme-1 expression in the bovine corpus luteum: implications for luteolysis. Endocrinology $\mathbf{1 4 2}$ 5254-5260. (https://doi.org/10.1210/endo.142.12.8550)

Li H, Chang HM, Shi Z \& Leung PCK 2018 SNAIL mediates TGF-beta1Induced downregulation of PENTRAXIN 3 expression in human granulosa cells. Endocrinology 159 1644-1657. (https://doi.org/10.1210/ en.2017-03127)

Liu C, Chang HM, Yi Y, Fang Y, Zhao F, Leung PCK \& Yang X 2019 ALK4-SMAD2/3-SMAD4 signaling mediates the activin A-induced suppression of PTX3 in human granulosa-lutein cells. Molecular and Cellular Endocrinology 493 110485. (https://doi.org/10.1016/j. mce.2019.110485)

Livak KJ \& Schmittgen TD 2001 Analysis of relative gene expression data using real-time quantitative PCR and the 2(-Delta Delta C(T)) Method. Methods 25 402-408. (https://doi.org/10.1006/meth.2001.1262)

Lonergan P \& Forde N 2015 The role of progesterone in maternal recognition of pregnancy in domestic ruminants. Advances in Anatomy, Embryology, and Cell Biology 216 87-104. (https://doi.org/10.1007/9783-319-15856-3_6)

Mann GE, Lamming GE, Robinson RS \& Wathes DC 1999 The regulation of interferon-tau production and uterine hormone receptors during early pregnancy. Journal of Reproduction and Fertility: Supplement $\mathbf{5 4}$ 317-328.

Mansouri-Attia N, Oliveira LJ, Forde N, Fahey AG, Browne JA, Roche JF, Sandra O, Reinaud P, Lonergan P \& Fair T 2012 Pivotal role for monocytes/macrophages and dendritic cells in maternal immune response to the developing embryo in cattle. Biology of Reproduction $\mathbf{8 7}$ 123. (https://doi.org/10.1095/biolreprod.112.101121)

Meidan R, Girsh E, Blum O \& Aberdam E 1990 In vitro differentiation of bovine theca and granulosa cells into small and large luteal-like cells: morphological and functional characteristics. Biology of Reproduction 43 913-921. (https://doi.org/10.1095/biolreprod43.6.913)

Moore RK, Otsuka F \& Shimasaki S 2003 Molecular basis of bone morphogenetic protein-15 signaling in granulosa cells. Journal of Biological Chemistry 278 304-310. (https://doi.org/10.1074/jbc.M207362200)

Norwitz ER, Schust DJ \& Fisher SJ 2001 Implantation and the survival of early pregnancy. New England Journal of Medicine 345 1400-1408. (https://doi.org/10.1056/NEJMra000763)

Oliveira JF, Henkes LE, Ashley RL, Purcell SH, Smirnova NP, Veeramachaneni DN, Anthony RV \& Hansen TR 2008 Expression of 
interferon (IFN)-stimulated genes in extrauterine tissues during early pregnancy in sheep is the consequence of endocrine IFN-tau release from the uterine vein. Endocrinology 149 1252-1259. (https://doi. org/10.1210/en.2007-0863)

Peng J, Li Q, Wigglesworth K, Rangarajan A, Kattamuri C, Peterson RT, Eppig JJ, Thompson TB \& Matzuk MM 2013 Growth differentiation factor 9:bone morphogenetic protein 15 heterodimers are potent regulators of ovarian functions. PNAS 110 E776-E785. (https://doi.org/10.1073/ pnas.1218020110)

Pierre A, Estienne A, Racine C, Picard JY, Fanchin R, Lahoz B, Alabart JL, Folch J, Jarrier P, Fabre S et al. 2016 The bone morphogenetic protein 15 up-regulates the anti-Mullerian hormone receptor expression in granulosa cells. Journal of Clinical Endocrinology and Metabolism 101 2602-2611. (https://doi.org/10.1210/jc.2015-4066)

Porter DA, Harman RM, Cowan RG \& Quirk SM 2001 Relationship of Fas ligand expression and atresia during bovine follicle development. Reproduction 121 561-566. (https://doi.org/10.1530/rep.0.1210561)

Przygrodzka E, Lopinska M \& Ziecik AJ 2014 Precision-cut luteal slices: a promising approach for studying luteal function in pigs. Reproductive Biology 14 243-247. (https://doi.org/10.1016/j.repbio.2014.04.001)

Przygrodzka E, Witek KJ, Kaczmarek MM, Andronowska A \& Ziecik AJ 2015 Expression of factors associated with apoptosis in the porcine corpus luteum throughout the luteal phase of the estrous cycle and early pregnancy: their possible involvement in acquisition of luteolytic sensitivity. Theriogenology 83 535-545. (https://doi.org/10.1016/j. theriogenology.2014.10.016)

Rajesh G, Mishra SR, Paul A, Punetha M, Vidyalakshmi GM, Narayanan K, Bag S, Bhure SK, Chouhan VS, Maurya VP et al. 2018 Transcriptional and translational abundance of bone morphogenetic protein (BMP) 2, 4, 6, 7 and their receptors BMPR1A, 1B and BMPR2 in buffalo ovarian follicle and the role of BMP4 and BMP7 on estrogen production and survival of cultured granulosa cells. Research in Veterinary Science $\mathbf{1 1 8}$ 371-388. (https://doi.org/10.1016/j.rvsc.2018.04.002)

Reader KL, Mottershead DG, Martin GA, Gilchrist RB, Heath DA, McNatty KP \& Juengel JL 2016 Signalling pathways involved in the synergistic effects of human growth differentiation factor 9 and bone morphogenetic protein 15. Reproduction, Fertility, and Development 28 491-498. (https://doi.org/10.1071/RD14099)

Roberts RM, Ealy AD, Alexenko AP, Han CS \& Ezashi T 1999 Trophoblast interferons. Placenta 20 259-264. (https://doi.org/10.1053/ plac.1998.0381)

Romero JJ, Antoniazzi AQ, Smirnova NP, Webb BT, Yu F, Davis JS \& Hansen TR 2013 Pregnancy-associated genes contribute to antiluteolytic mechanisms in ovine corpus luteum. Physiological Genomics 45 1095-1108. (https://doi.org/10.1152/physiolgenomics.00082.2013)

Salustri A, Garlanda C, Hirsch E, De Acetis M, Maccagno A, Bottazzi B, Doni A, Bastone A, Mantovani G, Peccoz PB et al. 2004 PTX3 plays a key role in the organization of the cumulus oophorus extracellular matrix and in in vivo fertilization. Development 131 1577-1586. (https://doi. org/10.1242/dev.01056)

Schmittgen TD \& Livak KJ 2008 Analyzing real-time PCR data by the comparative C(T) method. Nature Protocols 3 1101-1108. (https://doi. org/10.1038/nprot.2008.73)

Shimasaki S, Moore RK, Otsuka F \& Erickson GF 2004 The bone morphogenetic protein system in mammalian reproduction. Endocrine Reviews 25 72-101. (https://doi.org/10.1210/er.2003-0007)

Shrestha K \& Meidan R 2018 The CAMP-EPAC pathway mediates PGE2induced FGF2 in bovine granulosa cells. Endocrinology 159 3482-3491. (https://doi.org/10.1210/en.2018-00527)

Shrestha K, Lukasik K, Baufeld A, Vanselow J, Moallem U \& Meidan R 2015 Regulation of ovulatory genes in bovine granulosa cells: lessons from siRNA silencing of PTGS2. Reproduction 149 21-29. (https://doi. org/10.1530/REP-14-0337)

Sinderewicz E, Grycmacher K, Boruszewska D, Kowalczyk-Zieba I, Staszkiewicz J, Slezak T \& Woclawek-Potocka I 2017 Expression of factors involved in apoptosis and cell survival is correlated with enzymes synthesizing lysophosphatidic acid and its receptors in granulosa cells originating from different types of bovine ovarian follicles. Reproductive Biology and Endocrinology 15 72. (https://doi.org/10.1186/s12958-0170287-9)

Song T, Wang C, Guo C, Liu Q \& Zheng X 2018 PENTRAXIN 3 overexpression accelerated tumor metastasis and indicated poor prognosis in hepatocellular carcinoma via driving epithelial-mesenchymal transition. Journal of Cancer 9 2650-2658. (https://doi.org/10.7150/jca.25188)

Spencer TE, Ott TL \& Bazer FW 1996 Tau-interferon: pregnancy recognition signal in ruminants. Proceedings of the Society for Experimental Biology and Medicine 213 215-229. (https://doi.org/10.3181/00379727-21344053)

Tranguch S, Chakrabarty A, Guo Y, Wang H \& Dey SK 2007 Maternal PENTRAXIN 3 deficiency compromises implantation in mice. Biology of Reproduction 77 425-432. (https://doi.org/10.1095/ biolreprod.107.062414)

Varani S, Elvin JA, Yan C, DeMayo J, DeMayo FJ, Horton HF, Byrne MC \& Matzuk MM 2002 Knockout of pentraxin 3, a downstream target of growth differentiation factor-9, causes female subfertility. Molecular Endocrinology 16 1154-1167. (https://doi.org/10.1210/mend.16.6.0859)

Volpe E, Sambucci M, Battistini L \& Borsellino G 2016 Fas-Fas ligand: checkpoint of $\mathrm{T}$ cell functions in multiple sclerosis. Frontiers in Immunology 7 382. (https://doi.org/10.3389/fimmu.2016.00382)

Wertheimer T, Velardi E, Tsai J, Cooper K, Xiao S, Kloss CC, Ottmuller KJ, Mokhtari Z, Brede C, deRoos P et al. 2018 Production of BMP4 by endothelial cells is crucial for endogenous thymic regeneration. Science Immunology 3 eaal2736. (https://doi.org/10.1126/sciimmunol.aal2736)

Wheatley SP, Carvalho A, Vagnarelli P \& Earnshaw WC 2001 INCENP is required for proper targeting of Survivin to the centromeres and the anaphase spindle during mitosis. Current Biology 11 886-890. (https:// doi.org/10.1016/S0960-9822(01)00238-X)

Wheatley SP, Barrett RM, Andrews PD, Medema RH, Morley SJ, Swedlow JR \& Lens SM 2007 Phosphorylation by aurora-B negatively regulates survivin function during mitosis. Cell Cycle 6 1220-1230. (https://doi. org/10.4161/cc.6.10.4179)

Wheatley SP \& Altieri DC 2019 Survivin at a glance. Journal of Cell Science 132 jcs223826. (https://doi.org/10.1242/jcs.223826)

Yadav VK, Lakshmi G \& Medhamurthy R 2005 Prostaglandin F2alphamediated activation of apoptotic signaling cascades in the corpus luteum during apoptosis: involvement of caspase-activated DNase. Journal of Biological Chemistry 280 10357-10367. (https://doi.org/10.1074/jbc. M409596200)

Yang L, Wang XL, Wan PC, Zhang LY, Wu Y, Tang DW \& Zeng SM 2010 Up-regulation of expression of interferon-stimulated gene 15 in the bovine corpus luteum during early pregnancy. Journal of Dairy Science 93 1000-1011. (https://doi.org/10.3168/jds.2009-2529)

Yeh CM, Lin CW, Chuang CY, Liu YF, Chou CH, Yang SF \& Chen MK 2019 Functional genetic variant of long PENTRAXIN 3 gene is associated With clinical aspects of oral cancer in male patients. Frontiers in Oncology 9 581. (https://doi.org/10.3389/fonc.2019.00581)

Ying TH, Lee CH, Chiou HL, Yang SF, Lin CL, Hung CH, Tsai JP \& Hsieh YH 2016 Knockdown of PENTRAXIN 3 suppresses tumorigenicity and metastasis of human cervical cancer cells. Scientific Reports 629385. (https://doi.org/10.1038/srep29385)

Yu PB, Hong CC, Sachidanandan C, Babitt JL, Deng DY, Hoyng SA, Lin HY, Bloch KD \& Peterson RT 2008 Dorsomorphin inhibits BMP signals required for embryogenesis and iron metabolism. Nature Chemical Biology 4 33-41. (https://doi.org/10.1038/nchembio.2007.54)

Received 9 April 2020

First decision 12 May 2020

Revised manuscript received 16 July 2020

Accepted 21 July 2020 